\title{
Perlawanan Penyintas Body Shaming Melalui Media Sosial
}

\author{
Micheal, Suzy S. Azeharie \\ micheal.ana@gmail.com,suzya@fikom.untar.ac.id \\ Fakultas Ilmu Komunikasi Universitas Tarumanagara
}

\begin{abstract}
As the era progresses, technological advances bring ease in accessing information from various media, one of which is social media. One of the most popular social media is Instagram. Instagram is a social media that allows their users to share information in the form of images, videos or writings. But social media is often used as a means to mock individuals with the action of body shaming. Body shaming is an act of commenting on all aspects of one's body. Body shaming action occurs due to the ideal body standardization. The ideal body standardization differs from one place and culture, more often experienced by women. However some people resist the actions of body shaming experienced. Some body shaming survivors have courage to resist such an act by direct or social media resistance. The purpose of this research is to find out the form of resistance by the survivors of body shaming through Instagram. The study uses phenomenological research methods with qualitative descriptive approach. Research data is derived from depth interviews on five interviewees, observations, document studies and literature studies. The conclusion is the form of resistance of the survivors of body shaming through social media Instagram divided into two, open resistance and closed resistance. Adapted to the characteristics of body shaming survivors. The open resistance is characterized by an open interaction between the Group One and the other group. While hidden resistance is characterized by a closed interaction, indirect inter-group.
\end{abstract}

Keywords: body shaming, form of resistance, social media, instagram.

\begin{abstract}
Abstrak
Seiring perkembangan zaman, kemajuan teknologi menghadirkan kemudahan dalam mengakses informasi dari berbagai media, salah satunya media sosial. Salah satu media sosial yang digemari adalah Instagram. Instagram merupakan media sosial yang memungkinkan penggunanya untuk berbagi informasi dalam bentuk gambar, video maupun tulisan. Namun, media sosial kerap dijadikan sarana untuk mengejek individu dengan tindakan body shaming. Body shaming merupakan tindakan mengomentari segala aspek dalam tubuh seseorang. Tindakan body shaming terjadi karena standarisasi tubuh ideal. Standarisasi tubuh ideal berbeda-beda tergantung dari tempat dan budaya dan lebih sering dialami oleh perempuan. Namun, beberapa orang melawan dari tindakan body shaming yang dialami dan mereka disebut dengan penyintas. Beberapa penyintas body shaming berani melakukan tindakan perlawanan secara langsung maupun melalui media sosial. Tujuan penelitian ini adalah untuk mengetahui bentuk perlawanan yang dilakukan oleh penyintas body shaming melalui Instagram. Penelitian ini menggunakan metode fenomenologi dengan pendekatan deskriptif kualitatif. Data penelitian diperoleh dari wawancara mendalam, pengamatan langsung, studi dokumen dan studi kepustakaan. Kesimpulan penelitian ini adalah bentuk perlawanan penyintas body shaming melalui media sosial Instagram terbagi menjadi dua, yaitu bentuk perlawanan terbuka dan bentuk perlawanan tertutup disesuaikan dengan karakteristik penyintas body shaming. Perlawanan terbuka dikarakteristikkan dengan adanya interaksi terbuka antara kelompok satu dengan kelompok lainnya. Sementara perlawanan tersembunyi ditandai dengan adanya interaksi tertutup atau tidak langsung antar kelompok
\end{abstract}

Kata Kunci: body shaming, bentuk perlawanan, media sosial, instagram. 


\section{Pendahuluan}

Kemajuan teknologi menghadirkan kemudahan dalam mengakses informasi dari berbagai media, salah satunya media sosial. Hal ini kemudian berdampak pada penyebaran nilai-nilai yang dapat mempengaruhi perspektif masyarakat terhadap standarisasi tubuh ideal.

Standarisasi tubuh ideal berbeda-beda tergantung dari daerah dan budaya yang ada disekitarnya. Umumnya standarisasi tubuh diterapkan pada perempuan. Tubuh ideal, dalam hal ini penampilan fisik telah menjadi salah satu nilai utama terutama bagi perempuan. Menurut Barbara Watterson (2011) standarisasi tubuh ideal perempuan pada masa Mesir kuno memiliki badan kurus, kulit mulus, putih dan terlihat muda seperti dewi. Hal tersebut dapat dilihat dari penggambaran perempuan pada gambar di tembok maupun benda-benda peninggalan Mesir kuno.

Tubuh ideal perempuan menurut Ni Luh Rahayu Widiasti (2016), digambarkan dengan tubuh yang cenderung kurus, berlekuk, kuat dan sehat. Banyak perlakuan tidak adil dan diskriminasi yang terjadi terhadap perempuan yang tidak memenuhi kriteria kecantikan yang dipercayai pada saat itu. Hal ini dapat dilihat dalam kehidupan seharihari seperti banyak perusahaan yang saat ini memasukan tubuh ideal dan penampilan menarik sebagai salah satu kriteria bagi calon karyawannya seperti pegawai bank, sales promotion, pramugari dan masih banyak lagi.

Standar ideal tersebut kemudian membentuk citra tubuh pada masyarakat, khususnya pada perempuan. Menurut Rice dalam Akhmad Mukhlis (2013), citra tubuh atau body image merupakan gambaran secara mental mengenai tubuhnya. Citra tubuh menurut Nur Hasmawati (2017) mempengaruhi penerimaan diri terhadap lingkungannya. Semakin tinggi citra tubuh, maka semakin tinggi pula penerimaan diri seseorang terhadap dirinya. Namun ketika standar dan penilaian sulit dicapai maka dapat menimbulkan perasaan tidak puas terhadap kondisi diri. Pola pikir ini terus terbawa sehingga menimbulkan persepsi jika tidak memiliki bentuk tubuh ideal yang diharapkan.

Citra tubuh yang negatif dapat mengarah terhadap tindakan diskriminasi yang biasa lebih dikenal dengan istilah body shaming. Menurut Zulfikri Ikhlasul Qamal Bialangi, body shaming dapat dikategorikan sebagai bentuk dari kekerasan verbal atau yang lebih dikenal dengan sebutan bullying (2018). Secara singkat perilaku body shaming adalah menghina bentuk fisik seseorang yang tidak sesuai dengan standar ideal.

Tindakan body shaming biasanya dialami oleh individu yang dianggap tidak sesuai dengan standar kecantikan yang sedang berlaku sehingga kritik yang menjatuhkan mengenai bentuk tubuh sering dialami oleh individu. Individu yang bertahan dalam kondisi ini dikenal dengan sebutan penyintas body shaming. Menurut KBBI, penyintas adalah orang yang mampu bertahan. Penyintas dalam penelitian ini ditujukan terhadap individu yang pernah maupun sedang mengalami tindakan body shaming. Perlawanan menurut KBBI merupakan proses, cara, perbuatan, dan usaha untuk melawan suatu tindakan yang dialami. Bentuk perlawanan yang dilakukan penyintas body shaming menurut James C. Scott (1981) terdiri dari dua jenis yaitu perlawanan terbuka dan tertutup. Bentuk perlawanan yang dilakukan para penyintas tergantung dari kecocokan pribadi penyintas terhadap bentuk perlawanan yang akan dipilih. 
Dalam kemajuan teknologi saat ini, komentar pedas melalui media sosial sering dijumpai. Di ranah media sosial, artis hingga orang biasa bisa menjadi sasaran tindakan body shaming. Media sosial yang seharusnya menjadi tempat berbagi informasi beralih fungsi menjadi media untuk mencemooh penampilan fisik seseorang. Namun, melalui media sosial juga para penyintas dari body shaming menunjukan perlawananannya terhadap perlakuan tidak adil.

Berdasarkan judul penelitian di atas, rumusan masalah yang menjadi fokus penelitian ini adalah bagaimana bentuk perlawanan penyintas body shaming melalui media sosial Instagram?". Tujuan dari penelitian ini adalah untuk mengetahui bentukbentuk perlawanan yang digunakan penyintas body shaming melalui media sosial Instagram.

\section{Metode Penelitian}

Penelitian yang dilakukan oleh penulis menggunakan metode penelitian kualitatif. Metode penelitian kualitatif merupakan metode penelitian yang berfungsi untuk mencari makna, pemahaman, maupun pengertian mengenai suatu fenomena dan mengumpulkan data dengan melalui berbagai tahapan yang kemudian disimpulkan dari awal hingga akhir kegiatan (Yusuf, 2014). Penulis memilih pendekatan kualitatif karena sesuai dalam menggambarkan maksud dan tujuan dari penelitian penulis yaitu mengenai bentuk perlawanan yang dilakukan oleh penyintas body shaming melalui media sosial Instagram.

Dalam penelitian ini penulis menggunakan pendekatan deskriptif kualitatif dengan metode fenomenologi. Karena dengan pendekatan deskripif, penulis dapat melakukan pengamatan dengan lebih mendalam pada bentuk perlawanan penyintas body shaming melalui media sosial Instagram. Fenomenologi adalah studi yang membahas mengenai makna dan memandang segala perilaku yang dilakukan manusia merupakan produk dari penafsiran manusia terhadap hal yang bersangkutan (Kuswarno, 2009). Penulis menggunakan strategi penelitian fenomenologi karena ingin melihat fenomena yang terjadi dalam perlawanan yang dilakukan penyintas body shaming melalui Instagram.

Metode pengumpulan data yang penulis lakukan dalam penelitian ini adalah wawancara dengan narasumber, observasi dengan teknik non-partisipatif dan studi kepustakaan. Pengolahan data dalam penelitian kualitatif dilakukan dengan mengkategorikan data berdasarkan tema yang sesuai dengan fokus penelitian (Suyanto dan Sutinah, 2006). Hal ini memungkinkan temuan penelitian dapat diinformasikan kepada orang lain. Sebagai teknik analisis data, penulis melakukan wawancara dengan narasumber sebagai langkah dasar yang digunakan untuk mengamati atau observasi bentuk perlawanan yang dilakukan oleh penyintas body shaming melalui Instagram. Selanjutnya dari data yang diperoleh akan dianalisis untuk mengambil kesimpulan.

Teknik keabsahan data dalam penelitian ini dengan menggunakan teknik triangulasi dengan membandingkan data hasil observasi non-partisipatif dengan hasil wawancara dan pendapat ahli. Sehingga penulis dapat melakukan perbandingan dan juga pengecekan secara lebih mendalam. Teknik triangulasi adalah teknik keabsahan data yang memanfaatkan sesuatu yang lain. Teknik triangulasi yang banyak digunakan adalah pemeriksaan melalui sumber lainnya. Dengan triangulasi peneliti dapat melakukan pengecekan temuannya atau sebagai pembanding terhadap sumber, metode, atau teori lainnya (Moleong, 2012). 


\section{Hasil Temuan dan Diskusi}

Berdasarkan hasil wawancara penulis dengan satu informan ahli, dua key informan dan dua informan terungkap bahwa bentuk perlawanan terbagi menjadi dua, yaitu bentuk perlawanan terbuka dan bentuk perlawanan tertutup. Perbedaan dari kedua bentuk perlawanan ini terdapat pada karakteristik serta cara untuk menyampaikan pesannya.

Menurut Luviana, perlawanan yang saat ini dilakukan oleh penyintas body shaming berkembang mengikuti kemajuan teknologi dan dapat dilakukan melalui Instagram. Luviana sebagai seorang aktivis feminisme ikut membantu menyuarakan bentuk perlawanan terhadap ketidakadilan yang sering dialami perempuan melalui media sosial Instagram, buku dan juga film dokumenter yang sedang ia sosialisasikan yaitu More Than Work.

Key informan Ririe Bogar menggunakan bentuk perlawanan terbuka. Alasannya karena ia mengalami tindakan body shaming sejak berada di bangku Sekolah Menengah Pertama dan berlanjut hingga Ririe bekerja. Ririe memilih bentuk perlawanan terbuka karena dianggap lebih cepat dalam penyebaran informasi serta menunjukan perlawanan secara langsung mengenai tindakan body shaming yang dialami oleh dirinya dan juga orang lain. Sedangkan key informan Irene Permatasari Tanudibroto memilih bentuk perlawanan tertutup karena ia tidak merasa terbebani atas tindakan-tindakan tidak menyenangkan yang dialami dan hanya melakukan apa yang disukai, yaitu berfoto dan juga menampilkan diri apa adanya.

Berdasarkan hasil pengamatan, penulis melihat ada dua bentuk perlawanan yang berbeda antara Ririe dan Irene. Hal ini tampak ketika penulis melakukan observasi pada akun Instagram Ririe dan Irene. Penulis melihat bentuk perlawanan yang Ririe lakukan, yaitu dengan menggunakan tagar seperti \#komentarfisikgaasik maupun melalui unggahan dalam media sosial Ririe dan berbagai acara yang dilakukan Ririe bersama dengan model-model yang dinaungi agensi Ririe. Sedangkan dalam akun Instagram Irene penulis hanya melihat keseharian Irene sebagai seorang model dan juga dengan keluarga maupun teman-temannya. 
Gambar 1. Perbandingan unggahan Instagram Ririe dan Irene
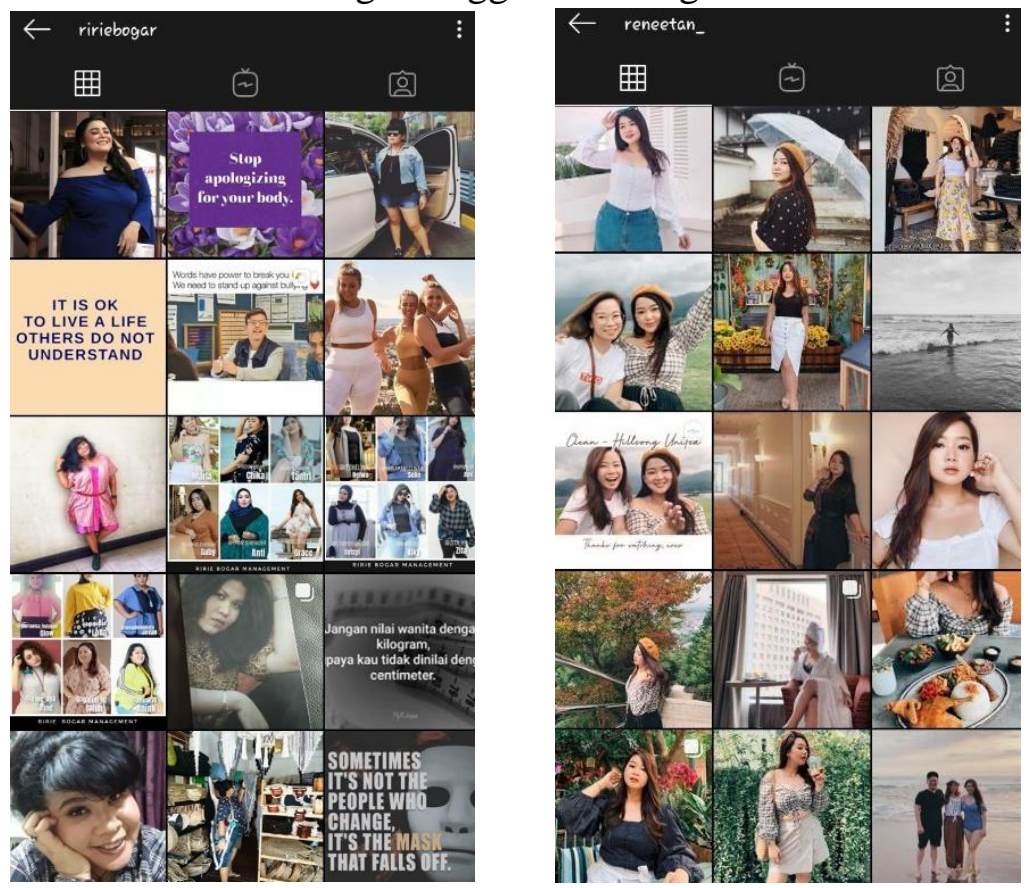

Sumber: Dokumentasi Penulis (2019)

Selain itu penulis menyadari bahwa bentuk perlawanan yang Ririe Bogar lakukan dapat mempengaruhi para pengikutnya untuk membantu menyebarkan perlawanan terhadap segala bentuk tindakan body shaming dan juga mengedukasi mengenai efek dari tindakan body shaming serta bagaimana cara untuk mulai berani melawan dan mencintai diri sendiri. Selain itu Ririe juga sering mengomentari langsung beberapa unggahan yang secara sengaja maupun tidak sengaja mengarah kepada tindakan body shaming dan tidak ragu untuk mengunggah ulang ke Instagram untuk menimbulkan efek jera.

Sedangkan pada akun Instagram Irene, Taniya dan Aldona tidak terlihat adanya perlawanan, melainkan hanya terlihat seperti akun Instagram lainnya yang membagikan kegiatan pekerjaan maupun aktivitas dan kebersamaannya dengan keluarga dan teman-temannya. Kendati demikian, tidak menutup kemungkinan jika tindakan body shaming bisa terulang dan tidak menimbulkan efek jera dan terkesan membiarkan tindakan body shaming untuk terus berlangsung.

Menurut Kamus Besar Bahasa Indonesia, perlawanan adalah proses, cara, perbuatan, dan usaha untuk melawan suatu tindakan yang dialami. Menurut James C. Scott (1981:69), perlawanan merupakan segala tindakan yang dilakukan oleh kelompok superdinat yang ditujukan untuk mengurangi ataupun menolak segala perilaku maupun peraturan yang dibuat oleh pihak atau kelompok subordinat yang ditujukan pada kaum lainnya. Berdasarkan hasil wawancara penulis dengan satu informan ahli, dua key informan dan dua informan menjelaskan bahwa bentuk perlawanan terbagi menjadi dua, yaitu bentuk perlawanan terbuka dan bentuk perlawanan tertutup yang dalam pemilihan bentuk perlawanan yang akan digunakan sangat bergantung pada karakteristik masing-masing penyintas tindakan body shaming.

Berdasarkan hasil wawancara dengan Ririe Bogar, bentuk perlawanan yang dilakukan oleh Ririe merupakan bentuk perlawanan terbuka. Alasan awal Ririe melakukan perlawanan terhadap tindakan body shaming karena ia mengalami tindakan 
body shaming pertamanya saat berada di bangku Sekolah Menengah Pertama, saat itu bobot tubuhnya mencapai hingga $80 \mathrm{~kg}$. Kemudian tindakan body shaming ini kembali dialami saat bekerja di bidang travel and tourism saat bobot tubuhnya mencapai $90 \mathrm{~kg}$ dengan tinggi $160 \mathrm{~cm}$.

Pada tahun 2005, Ririe Bogar mengikuti acara Miss Big Indonesia. Miss Big Indonesia adalah ajang kontes kecantikan yang dilakukan oleh Kementerian Kehutanan sejak tahun 2007 untuk perempuan bertubuh besar. Kontes ini diikuti oleh perempuan usia 19 tahun ke atas, belum menikah, dan berdomisili di Jabodetabek. Untuk memenangi kontes ini, peserta harus memenuhi lima kriteria dari para juri, yaitu big, beauty, brain, behaviour, dan believe, yang disingkat sebagai 5B (https://nasional.kompas.com/read/2010/09/24/1734012/Miss.Big.Indonesia.Utamak an.5B yang diakses pada 14 Desember pukul 00:41). Setelah mengikuti ajang Miss Big Indonesia Ririe memiliki ide untuk membuka butik khusus wanita berbadan besar yang berkembang menjadi komunitas Xtra-L. Komunitas Xtra-L saat ini berkembang menjadi plus size Model Management yang menaungi lebih dari 20 model perempuan plus size. Seiring dengan perkembangan bisnisnya, Ririe Bogar ikut berkembang menjadi seorang influencer plus size dan menyebarkan bentuk-bentuk perlawanan terhadap tindakan body shaming di Instagram sejak Februari 2015.

Perlawanan terbuka yang dilakukannya adalah membuat unggahan melalui Instagram mengenai ejekan yang dialami dan kemudian ia sebarkan melalui Instagram peribadinya dalam bentuk video maupun foto atau ilustrasi kepada 36400 pengikut akun Instagramnya. Selain itu Ririe Bogar membuat tagar yang sering digunakan saat mengunggah konten ke dalam akun Instagramnya. Salah satu tagar yang dibuat oleh Ririe Bogar adalah \#komentarfisikgaasik. Selain itu Ririe Bogar juga membuat manajemen yang menaungi model-model dengan bentuk tubuh yang berisi dan sering juga mengadakan acara talk show maupun fashion show untuk meningkatkan rasa percaya diri untuk para perempuan yang memiliki bentuk tubuh yang berisi. Ririe Bogar sering menulis komentar secara langsung terhadap akun-akun yang secara sengaja maupun tidak sengaja melakukan tindakan body shaming walau tidak ditujukan langsung terhadap dirinya.

Menurut Ririe Bogar, semenjak ia melakukan perlawanan terbuka, komentar negatif mengenai bentuk tubuhnya mulai berkurang. Selain itu banyak pengikut Ririe Bogar yang merasa terinspirasi untuk melakukan perlawanan terhadap tindakan body shaming. Selain itu ada beberapa pengikut Instagram yang merupakan seorang penyintas body shaming mulai berani untuk ikut melakukan perlawanan terhadap segala bentuk tindakan body shaming setelah mengikuti akun Instagram Ririe.

Bentuk perlawanan yang dilakukan oleh Irene Permatasari Tanudibroto merupakan bentuk perlawanan tertutup terhadap tindakan body shaming. Irene mengawali perlawanan body shaming sejak tahun 2014 dengan mengunggah fotonya dengan berbagai model baju. Saat ini Irene telah menjadi model dari beberapa merek ternama, salah satunya adalah merek pakaian dalam perempuan. Menurut Irene, perlawanan yang dilakukan tidak perlu disampaikan secara langsung, melainkan untuk memotivasi dirinya sendiri bahwa menjadi menarik tidak harus memiliki tubuh yang kurus. Selain itu, Irene ingin memberikan inspirasi terhadap perempuan-perempuan plus size lainnya, walaupun memiliki tubuh yang berisi tidak berarti mereka tidak dapat terlihat cantik dan menarik. Dengan pemilihan pakaian yang tepat serta rasa percaya diri yang tinggi sudah cukup untuk menjadi seseorang yang cantik. 
Di tempat lain Taniya seorang mahasiswa Fakultas Hukum dari Universitas Trisakti mengalami tindakan body shaming sejak masa Sekolah Dasar dalam bentuk olokan maupun cacian mengenai bentuk tubuhnya yang dianggap besar dan memiliki warna kulit gelap. Kemudian ejekan dan cacian mengenai tubuhnya masih berlanjut hingga Taniya dewasa melalui media sosial maupun dalam kehidupannya sehari-hari. Tidak jarang Taniya mengalami ejekan bahkan dari orang yang tidak dikenalnya. Hal yang sering menjadi bahan olok-olokan tentang warna kulitnya yang gelap hingga ukuran payudara yang dianggap terlalu besar. Namun, Taniya berpendapat bahwa ia memiliki kontrol atas dirinya sendiri dan informasi mana yang perlu didengar dan informasi mana yang perlu dilupakan. Taniya tidak terlalu mempedulikan ejekan yang ditujukan terhadap bentuk tubuhnya yang dianggap oleh orang-orang tidak ideal. Selama ia merasa nyaman terhadap tubuhnya maka ia tidak merasa takut untuk mengunggah gambar maupun video mengenai tubuhnya. Namun tidak jarang secara tidak sadar Taniya merasa kecewa terhadap orang-orang disekitarnya yang menjadikannya bahan ejekan walau hanya bercanda.

Aldona Nevi Caroline mengalami tindakan body shaming sejak berusia 14 tahun dalam bentuk candaan mengenai bentuk tubuhnya yang dianggap lebih berisi dari orang-orang lainnya hingga saat ini dalam bentuk candaan. Namun, Aldona memilih untuk tidak terlalu memikirkan hal yang dikatakan orang-orang mengenai bentuk tubuhnya yang dianggap tidak ideal dan juga tidak menarik seperti perempuan lainnya. Aldona merasa nyaman dengan tubuhnya dan ia memilih menggunakan Instagramnya sebagai media untuk mengekspresikan dirinya dan segala hal yang ia sukai. Konten Instagram yang Aldona unggah seperti berbagai foto maupun video mengenai teman, keluarga, dan hal lainnya yang ia ingin bagikan kepada pengikut Instagramnya.

\section{Simpulan}

Berdasarkan hasil penelitian dan pembahasan diatas, maka dapat disimpulkan beberapa poin utama yang menjadi hasil penemuan dalam penelitian ini. Pertama, body shaming adalah tindakan mengomentari segala aspek yang ada dalam tubuh seseorang. Kedua, body shaming merupakan bentuk komunikasi dengan konotasi yang negatif dan berakibat buruk bagi penyintasnya. Akibat buruk yang dimaksud yaitu timbulnya rasa malu, kurangnya perasaan untuk mencintai dirinya sendiri dan bahkan dapat menurunkan kepercayaan diri penyintasnya. Ketiga, bentuk perlawanan dari penyintas body shaming melalui media sosial Instagram terbagi menjadi dua bentuk yaitu, bentuk perlawanan terbuka dan bentuk perlawanan tertutup. Perlawanan terbuka adalah bentuk perlawanan yang disampaikan secara umum dan langsung. Sedangkan bentuk perlawanan tertutup adalah bentuk perlawanan yang disampaikan secara tertutup. Keempat, bentuk perlawanan terbuka tindakan body shaming melalui Instagram disampaikan dalam bentuk tagar seperti \#komentarfisikgaasik \#stopbodyshaming \#cantikituejaannyabukankurus, komentar untuk menjawab langsung pertanyaan secara sengaja maupun tidak sengaja yang mengarah kepada tindakan body shaming, membentuk komunitas model dengan ukuran plus size, mengambil gambar mengenai tindakan body shaming yang kemudian diunggah ke dalam akun Instagram dan membuka butik untuk perempuan dengan ukuran plus size. Sedangkan bentuk perlawanan tertutup tindakan body shaming berupa foto dan video mengenai hal yang diinginkan maupun disukai. Kelima, perbedaan bentuk perlawanan 
terbuka dan bentuk perlawanan tertutup pada tindakan body shaming terletak pada karakterisik dan cara dalam penyampaiannya.

Bentuk perlawanan yang dilakukan penyintas tindakan body shaming terbagi menjadi dua, yaitu bentuk perlawanan tertutup dan terbuka. Perlawanan terbuka merupakan bentuk perlawanan yang disampaikan secara langsung berupa tagar seperti \#komentarfisikgaasik \#stopbodyshaming \#cantikituejaannyabukankurus, komentar untuk menjawab langsung pertanyaan secara sengaja maupun tidak sengaja yang mengarah kepada tindakan body shaming, membentuk komunitas model dengan ukuran plus size, mengambil gambar mengenai tindakan body shaming yang kemudian diunggah ke dalam akun Instagram dan membuka butik untuk perempuan dengan ukuran plus size. Sedangkan, bentuk perlawanan tertutup tindakan body shaming berupa foto dan video mengenai hal yang diinginkan maupun disukai. Perlawanan terbuka dapat menimbulkan efek jera terhadap individu maupun kelompok yang secara sengaja maupun tidak sengaja melakukan tindakan body shaming. Sedangkan perlawanan tertutup tidak memberikan efek jera, namun dapat memberikan perasaan nyaman dalam berekspresi sesuai keinginannya tanpa mempedulikan komentar yang tidak ingin diperdulikannya serta penyampaian bentuk perlawanan yang dilakukan oleh penyintas body shaming disampaikan secara santun.

\section{Ucapan Terima Kasih}

Pada kesempatan ini, penulis mengucapkan terima kasih kepada pihak-pihak yang telah banyak membantu dan memberi dukungan yang sangat luar biasa selama penelitian ini, yaitu kelima narasumber penulis yaitu Luviani, Ririe Bogar, Irene Permatasari Tanudibroto, Taniya dan Aldona Nevicaroline; keluarga dan teman-teman terdekat penulis yang terus memberikan motivasi dan doa kepada penulis.

\section{Daftar Pustaka}

Azeharie, Suzy. (2012). Representasi Perempuan Pelaku Kejahatan Dalam Media Sosial Analisis Kasus Afriani Susanti. Jurnal Komunikasi Universitas Tarumanagara.

Bialangi, Zulfikri.I.K. (2018). Fenomena Body Shaming Terhadap Perempuan Dalam Upaya Preventif, Represif Dan Social Planning. Jurnal Psikologi.

Hasmilawati, Nur. (2017). Pengaruh Citra Tubuh Dan Perilaku Makan Terhadap Penerimaan Diri Pada Wanita. Jurnal Psikoislamedia Volume 2 Nomor 2.

Kuswarno, Engkus. (2009). Metode Penelitian Komunikasi: Fenomenologi, Konsepsi, Pedoman dan Contoh Penelitiannya. Bandung: Widya Padjadjaran.

Moleong, Lexy L. (2012). Metodologi Penelitian Kualitatif. Edisi Revisi. Bandung: P.T. Remaja Rosdakarya

Mukhlis, Akhmad. (2013). Berpikir Positif Pada Ketidakpuasan Terhadap Citra Tubuh (Body Image Dissatisfaction). Jurnal Psikodinamika

Scott. James.C. (1981). Domination And The Arts Of Resistance: Hidden Transcripts. New Haven, CT : Yale University Press

Watterson, Barbara. (2011). Women In Ancient Egypt. Gloucestershire : Amberley Publishing

Widiastini, Ni.L.R. (2016). Profil Citra Tubuh Pada Remaja Dan Implikasinya Bagi Bimbingan Konseling: (Studi Deskriptif Terhadap Peserta Didik Kelas XI 
SMA Negeri 1 Sukaresmi Kabupaten Cianjur Tahun Ajaran 2015-2016). Skripsi

Yusuf, Muri. (2014). Metode Penelitian: Kuantitatif, Kualitatif dan Penelitian Gabungan. Jakarta: Prenada media Group

$<$ https://nasional.kompas.com/read/2010/09/24/1734012/Miss.Big.Indonesia.Utamak an.5B> 